\title{
Semantic and Pragmatic Mechanisms of Humour in Animal Jokes
}

\author{
Attila L. NEMESI \\ Pázmány Péter Catholic University (Budapest, Hungary) \\ Department of Hungarian Linguistics \\ nemesi.attila@btk.ppke.hu
}

\begin{abstract}
The purpose of this paper is to take a close look at the interplay of semantic and pragmatic components of animal jokes. Rather than insisting on the priority of one particular theoretical tradition and selecting a few illustrative examples, 30 animal jokes - most of them translated into English from Hungarian - are presented to help identify the different mechanisms that make them amusing. Adopting a theory-by-theory approach, it becomes clear that some jokes fit well the explanation of frame or script semantics, while others are best captured by one or another pragmatic framework and classification. This leads to the related question of whether it is possible, at this stage of research, to integrate the diverse lines of thought or whether the semantic and pragmatic study of verbal humour will have to remain relatively fragmented. It is argued that certain basic elements of major pragmatic theories are important complements to frame/script semantics, the humour of animal jokes is reliant on the same meaning-generating processes as observed in other jokes, and that the attraction of animal jokes lies in their psychological and cultural-anthropological characteristics. Finally, their cross-cultural investigation is encouraged.
\end{abstract}

Keywords: animal jokes, frames, scripts, speech acts, conversational maxims, implicature, explicature, relevance theory, viewpoints

\section{Introduction}

Animal jokes are a well-known and much-liked thematic group of jokes. In the present paper, I seek to answer the question whether animal jokes are a special type of jokes semantically and pragmatically or whether they use the same humourtriggering mechanisms as do other jokes and genres of humour. I rely on five theoretical frameworks in doing so: frame- and script-based semantics, speech act theory, Gricean and neo-Gricean pragmatics, relevance theory, and functional cognitive pragmatics. From a cognitive semantic perspective, my aim is to highlight 
the importance of drawing a principled distinction between frames and scripts that is applicable to jokes (and humorous texts in general). From a pragmatic point of view, I attempt to demonstrate the fundamental role some key pragmatic phenomena play in creating humour in animal jokes, arguing for the need for an integrative approach. The psychological and cultural-anthropological appeal of animal jokes is also worth yet another closer look. For comparison, I briefly discuss and test a relatively new typology of humour, dubbed the Intersecting Circles Model (Yus 2013, 2016), which distinguishes seven types of jokes. Most of the jokes cited as examples are taken from Hungarian collections of jokes and translated into English in the main text (the Hungarian versions are provided in footnotes), although in some cases original English-language jokes are chosen in order to avoid translation difficulties arising from polysemy, homonymy, homography, homophony, or paronymy.

\section{Jokes and animal jokes}

Even though the boundaries of the notion are rather fluid (cf. one-liners, banter, humorous anecdotes, cartoons with captions, Internet memes, etc.), a joke is primarily a short, fictional story with a surprising punch line at the end whose goal is to create a humorous effect in the audience/readers/viewers. It can be considered a text type or a discourse genre, so the focus is on either the linguistic form or the communicative function (see e.g. Attardo 1994: 293-331, Attardo and Chabanne 1992, Hetzron 1991, Norrick 1993). The prototypical (canned) joke has an unknown author, no title, and a non-canonical text passed on from speaker to speaker, in which a one- or two-sentence-long narrative introduction is followed by a short dialogue (or polylogue), the last turn of which contains the punch line. This scheme is not rigid: the narrative introduction is often absent if the background information necessary to understand the punch line can be gathered from the dialogue (1) or when the joke is a riddle or conundrum, with the "dialogue" being a pseudo-dialogue (2):

(1) Mother: "Billy, why did you pull the cat's tail?"

Billy: "I didn’t pull her tail, mom. I was standing on it, and she pulled it." (AA. 17)

(2) Q: "What does a rabbit use to comb its fur?" A: "A harebrush."

(AA. 31)

Rarely, the dialogue may actually be absent: 
(3) The fox, the stork and the jackass plan a trip and agree to bring their partners along.

The fox brings his chick, the stork his babe, and the jackass his wife. ${ }^{1}$

(LVk. 46)

Most jokes, however, follow the structure of the joke in (4):

(4) Mama stork sends her three fledglings out to learn about life. A few months later, she calls them back to the nest and asks them to tell her what they have accomplished.

The oldest fledgling boasts, "I delivered triplets to the grocer!"

The second one says, "I delivered quintuplets to an army officer."

“And you?" the mama stork asks her youngest fledgling.

"I'm still too small and weak to deliver babies, but I managed to scare the young woman behind the cash register pretty badly." 2

(AK. 84-85, HÁv. 138-139, LÁv. 29-30, LVk. 41)

Joke book editors as well as non-experts categorize jokes according to thematic groups. In the Hungarian language area, the most popular jokes include absurd jokes, animal jokes, artist jokes, blonde jokes, child jokes, doctor jokes, driver jokes, drunk jokes, exotic jokes, gangster jokes, Gypsy jokes, historical jokes, Jewish jokes, madman jokes, marriage jokes, mother-in-law jokes, policeman jokes, politician jokes, restaurant jokes, school jokes, scientist jokes, Scotsman jokes, sex jokes, and Szekler jokes (cf. the chapters of LVk.). Other cultures have their own preferred joke topics: for instance, lawyer jokes are very widespread in the United States (cf. Davies 2011, T. Litovkina 2016a).

There are many reasons for the general appeal of animal jokes. Of course, we need to clarify what an animal joke is to begin with since in collections of jokes fisherman jokes and hunter jokes are frequently subsumed under the heading of “animal jokes” even when no animal appears in the joke at all, as in (5):

(5) "Why are you so stressed?"

"Because I'm fishing."

"I thought fishing calmed the nerves."

1 A róka, a gólya és a marha közös kirándulást terveznek, s megbeszélik, hogy mindegyikük viszi magával a partnernőjét is. A róka elviszi a tyúkját, a gólya a babáját, a marha pedig a feleségét.

2 A gólyamama kiküldi az életbe három fiókáját, hogy önállósodjanak. Néhány hónap múlva visszahívja ôket a családi fészekbe, hogy számoljanak be élményeikról.

- Én hármas ikreket vittem a füszereshez - dicsekszik a legidősebb.

- Én ötös ikreket egy katonatisztnek - mondja a második.

- És te? - fordul a gólyamama a legkisebbhez.

-Én még kicsi és gyenge vagyok a gyerekcipeléshez, de a pénztáros kisasszonyra jól ráijesztettem. 
"Only if you have a fishing license." 3

(HÁv. 26, LVk. 30)

Although the notion of fisherman is no doubt closely connected with that of fish, the joke in (5) is not an animal joke (at best, an animal-related one) in the sense that in animal jokes animals talk or do something, and, if not, at least one animal species is named in them (cf. (1)-(4)). The dialogue of a prototypical animal joke is carried out between animals (i.e. interanimal communication) or between one (or more) animal(s) and one (or more) person(s) (i.e. human-animal communication). Two of the main characteristics of animal jokes are that they emphasize or even exaggerate the most salient features of animals (the slowness of the snail, the long neck of the giraffe, etc.), and they anthropomorphize animals (cf. Andor 2002, 2014, 2018). Some animal jokes zoomorphize instead: for instance, humans can understand or speak the "language" of animals, behave like an animal (cf. T. Litovkina 2016b), and have sex with animals:

(6) An entertainer arrives in a village and says to one of the farmers, "I understand the language of animals. If you invite me to your house for dinner, I can tell you which animal has a problem." The farmer invites the entertainer to his house. They go up to the cow, and the entertainer says, "She is complaining of an aching udder because she was not milked properly." They go on to the rooster, which is crowing painfully. "He says the chickens didn't get enough hatching feed." Suddenly, a goat runs to them, bleating happily. The farmer looks at his guest in dismay and blurts out, "Don’t you believe a word this lying beast says!"

(LVk. 43)

Human-animal relationships go back to the dawn of humanity, and animal myths are as common in the cultures of the world as are animal symbols. Folklore studies consider animal tales as a subgenre of folktales and fairy tales, while linguistics focuses attention on the phraseology in animal proverbs and sayings (e.g. Forgács 2005, Haase 2008, Mieder 1993, Szirmai et al. 2018, Werness 2003).

3 - Miért ilyen ideges?

- Mert horgászom.

- Azt hittem, az nyugtat.

- De csak azt, akinek van horgászengedélye.

4 Mutatványos érkezik a faluba. Azt mondja az egyik gazdának:

- Én értek az állatok nyelvén. Ha meghív ebédre, megmondom, melyiknek mi a baja.

A gazda rááll a dologra. Odamennek a tehénhez, s azt mondja az állatértó:

- Szegény arról panaszkodik, hogy fáj a tőgye, mert nem fejték meg rendesen.

Mennek tovább. A kakas hangosan, fájdalmasan kukorékol.

- Azt mondja, hogy a tyúkok nem kaptak elég tojótápot.

Ekkor vidám mekegéssel elébük szalad a kecske. A gazda megdermed, és habogva mondja a vendégnek:

- Egy szavát se higgye el ennek a hazug dögnek. 


\section{Scripts, frames, and schemas}

Some humour researchers prefer to investigate jokes for methodological reasons, i.e. their relatively short, fairly homogeneous, and easily accessible nature, drawing conclusions about humour on the basis of analysing them (Hetzron 1991, Raskin 1985, Ritchie 2004). Perhaps the most influential linguistic hypothesis regarding jokes is Raskin's (1985, revised and further developed as Attardo and Raskin 1991), according to which a text is a joke if it is compatible with two distinct scripts, these scripts overlap fully or in part but clash in a special predefined sense, evoking actual/non-actual (existing/non-existing), normal/abnormal (expected/ unexpected), or plausible/implausible (possible/impossible, much less possible) states of affairs. What can trigger the switch from the first script to the second is ambiguity or contradiction. Consider the syntactic ambiguity of the opening utterance in (7), more effective in oral performance. The two scripts here are SHARK ATTACK and RESTAURANT.

(7) "I just saw a man eating shark."

"Where??"

"In a restaurant."

(AA. 76)

Interestingly, thanks to Schank and Abelson's (1977) ground-breaking work in cognitive psychology and artificial intelligence, RESTAURANT has become the most famous textbook example of scripts. As they assert, "a script is a predetermined, stereotyped sequence of actions that defines a well-known situation" (1977: 41). It allows us to tell and understand a story in an economical way, leaving out what is unnecessary or retrievable from this knowledge structure stored as an interconnected whole in the long-term memory. The compactness of joke texts is largely due to the schematic mental representations we have of things and of a wide range of social settings. Several types of scripts can be described: for example, in contrast to simple or concrete scripts, metascripts consist of scenes with a minimum of specification such as doing standard favours, empathic helping, visiting a health professional, and the like (Abelson 1981: 725). At a higher level of abstraction, therefore, we may have a FAIRY TALE metascript, of which the story of Little Red Riding Hood is a concrete realization. If a joke begins with "Little Red Riding Hood and her grandmother...", a listener who grew up in our culture will immediately recall the script of the tale with the Big Bad Wolf as the third main character:

(8) Little Red Riding Hood and her grandmother are wondering what could be up with the wolf since they had not seen him for days. Could something have happened to him? So, they decide to visit him. They knock on the door of the 
wolf's den, and in a short while the wolf appears, looking awful: he is pale, his face is gaunt, with bags under his eyes.

"What's up with you, wolf, are you sick or something?"

"Oh no, not at all. It's just that I had to dance with Kevin Costner all night..." (AK. 43)

Notice that the narrative introduction in (8) breaks with the LITTLE RED RIDING HooD script by inventing that the little girl and her grandmother decide to visit the wolf because they worry about him. Then, in accordance with Raskin's (1985) hypothesis, the punch line switches from this modified first script to another one: that of the Oscar-winning 1990 movie Dances with Wolves starring Kevin Costner.

At first glance, it might appear that the idea of script opposition as the source of humour is on the right track, especially if we adopt Raskin's broad view of scripts as large chunks of semantic information surrounding the word or evoked by it (1985: 81) and not restricted to stereotyped event sequences (cf. Schank and Abelson 1977). Unfortunately, the terminology within frame semantics is far from consistent, as is clear from the following alternatives to script opposition in humour literature: "schema conflict” (Norrick 1986), "frame-shifting” (Coulson 2001), "frame and scriptal break" (Andor 2002). This is obviously not the place to offer an overview of various approaches to the relationship between schema, frame, script, scenario, scene, and other similar notions (see e.g. Andor 1986, Attardo 2001: 2-8). To me, however, it seems quite counterintuitive to suppose that there exist "atemporal scripts” (Raskin 1985: 126). Instead, I will remain closer to Schank and Abelson's definition, using schema as an umbrella term, frame for the network of conceptual associations around a word (cf. "a graph with lexical nodes and semantic links between them”, “a lexical script”; Attardo 2001: 7, Raskin 1985: 81), and script as synonymous with scenario. This is not to deny that frames as lexical domains and scripts as higher-order packages of information are related to one another.

The joke in (9) does not involve script switching. It stays within the WALKING THE DOG AND PETTING IT script from beginning to end, yet it is funny because Danny wants to satisfy his curiosity at the expense of Johnny's well-being:

(9) Danny is walking his new dog when he runs into Johnny.

"Oh, what a cute dog you have!"

"Go ahead, pet him!"

"He doesn’t bite, does he?"

$5 \quad$ Piroska és a nagymama azon tanakodnak, mi lehet a farkassal, merthogy már napok óta nem látták. Talán valami baj érte? Elhatározzák, hogy meglátogatják. Bekopogtatnak a farkasbarlang ajtaján. Kisvártatva kijön a farkas, szörnyen néz ki: sápadt, beesett a pofacsontja, karikásak a szemei.

- Mi van veled, farkas koma, talán beteg vagy?

- Ugyan, dehogy. Csak egész éjjel Kevin Costnerrel kellett táncolnom. 
"That's what I'd like to find out!"6

(HÁv. 116, LÁv. 69, LVk. 37)

The question arises how this joke fits into any semantic theory of humour. Impoliteness is a pragmatic phenomenon, and (9) is best understood as a violation of Leech's $(1983,2014)$ politeness maxims (Tact, Generosity, Sympathy).

Andor $(2002,2014,2018)$ stresses, rightly in my view, the importance of frames in animal jokes. These frames internalize objective characteristics, personal experience, cultural stereotypes or beliefs - the point is that they are relatively unified within a given community. That is why animal jokes can be based on them. For instance, snails, as we know, move slowly, a fact that the joke in (10) greatly exaggerates:

(10) A curious snail crawls up an oak tree. It crawls and crawls. Fifty years pass. Then another fifty years pass. Then, half way up, the snail slides off and falls back to the ground. It hurts itself really badly and says resentfully: "See? That's what hurrying does to you!"”

(AK. 67; HÁv. 136; LVk. 36)

Does (10) break or switch the SNAIL frame or the CLIMBING UP THE TREE script? The answer is surely "no" (except that the snail speaks like humans do); rather, slowness as a salient behavioural feature of snails is extremely exaggerated and perspectivized in it.

Other animal jokes borrow frames or scripts from various fields of human experience that have nothing to do with animals. The joke in (11) requires knowledge of what people in East-Central Europe generally think about "the communist party" or communist parties of the former Eastern Bloc led by the Soviet Union (cf. Raskin 1985: 242):

(11) The rabbit is running east in the Siberian steppe when he is stopped by the fox. "Where are you running, Rabbit?"

"The Communist Party decided that all five-legged rabbits will be shot."

"But you only have four legs..."

6 Új kutyáját sétáltatja Peti, amikor találkozik Sanyikával.

- Jaj, de aranyos kutyád van!

- Simogasd meg!

- De nem harap?

- Ezt szeretném én is megtudni.

7 Egy kíváncsi csiga felmászik a tölgyfára. Mászik, mászik. Eltelik ötven év, majd még ötven. Akkor - talán félúton - a csiga véletlenül megcsúszik, és visszahuppan a földre. Keservesen megüti magát, s bosszúsan mondja:

- Na lám csak! Ez a vége a nagy sietségnek! 
"Yeah, but these guys shoot first and count second..."

(AK. 46)

No matter how they are labelled at the "meta-" and the concrete level, such underlying scripts interact with the animal frames as is the case in (11) with the RABBIT frame, which involves that rabbits run fast and hide from predators and hunters. One might argue that the COMMUNIST PERSECUTION script breaks the RABBIT frame, or the latter is embedded in the former, but the punch line does not serve to reveal script opposition or frame clash.

While it is indisputable that scripts and frames are useful cognitive semantic notions, there is no reason to ignore the pragmatic side of the coin in attempting to develop a full-fledged joke theory and, more widely, the understanding of humour. The whole process of text interpretation is tightly interwoven with pragmatic inferences, including the recognition of intention and contextual manipulation. For further discussion and criticism of the semantic script theory of humour and its later versions, see e.g. Attardo 1994, 2001, Brock 2004, Dynel 2009, Morreall 2004, Oring 2019, Raskin 2017, Raskin et al. 2009, Ritchie 2004, Yus 2016, and Kianbakht 2020. My claim here is that the humour of animal jokes can spring from breaking or switching frames or scripts, from combining or manipulating them, and that these operations incorporate several pragmatic factors.

\section{Animal jokes as speech-act jokes}

The founding fathers of speech act theory (Austin 1962, Searle 1969) were somewhat reluctant to examine in detail the nature and "felicity conditions" (Austin's term) of non-serious and insincere speaker intentions expressed in the course of communication. In reality, however, humorous speech acts abound (Goatly 2012: 205-223, Hancher 1980, Nemesi 2016), and a number of far-reaching conclusions can be drawn from them for the theory itself. Locution, illocution, and perlocution can all function as the key elements of a joke's punch line, and it is important to add that humour, either intentional or unintentional, is closely intertwined with and often defined by its most frequent perlocutionary effect, i.e. amusement and laughter (Alexander 1997: 65, Attardo and Chabanne 1992: 168).

First, let us take a joke based on locution:

8 Nyuszika fut eszeveszetten a szibériai pusztán keletnek, amikor megállítja a róka:

- Hová futsz, nyuszika?

- A kommunista párt úgy döntött, hogy kilövik az ötlábú nyulakat...

- De hiszen neked csak négy lábad van!

- Ja, de ezek előbb lőnek, aztán számolnak... 
(12) Little worm: "Am I late, mother?"

Mother worm: "Yes! Where in earth have you been?"

(AA. 25)

Locutionary jokes are typically language-specific. In the above example, the common question "Where on earth have you been?" is replaced by "Where in earth have you been?”, with a different preposition, in an untranslatable twist. For Austin (1962: 95), the rhetic act is the performance of an act of using "certain vocables or words [...] with a certain more-or-less definite sense and reference"; this is the level at which the humour of the joke in (12) can be interpreted according to his classification and at the level of propositional acts in Searle's (1969) framework.

Secondly, the most central category of speech act theory is the illocutionary act. Searle (1965) regarded it as the minimal unit of linguistic communication. There are many kinds of jokes based on illocution. A typical one, a contemporary so-called Hungarian “aggressive piglet” joke (cf. Andor 2014: 42) involving the misunderstanding of the illocutionary act and a response that follows from it, is presented in (13):

(13) The aggressive piglet is riding on the bus. A ticket inspector comes:

“Tickets, monthly passes, please!”

The piglet says, "I don’t want any!"”

(AK. 6)

The directive (or exercitive, in Austin's terms) illocutionary act performed by the ticket inspector is not an offer or begging, as interpreted by the aggressive piglet, a character whose aggressiveness is his defining attribute, accompanied by his imperfect pragmatic competence (also see below).

Finally, the humour of the joke in (14) is based on perlocution because by speaking as a human the dog scares old Uncle Steve (unintentional effect), even though that is exactly what it wanted to avoid:

(14) Old Uncle Steve goes to visit a friend of his. At his friend's house, he shouts over the fence, at which point an enormous Komondor ${ }^{10}$ runs up and says:

"My owner is not home!"

Uncle Steve faints. The dog licks his face, and when he comes round, he asks: "Hey, can't you bark or something?"

9 Az agresszív kismalac autóbuszon utazik. Jön az ellenőr:

- Jegyeket, bérleteket!

Mire a kismalac:

- Nem kell!

10 The Komondor is a large, white-coloured traditional Hungarian breed of livestock guard dog renowned for its long, corded coat. 
“Oh, yes, I can, but I didn't want to scare you!"11

(AK. 58, LVk. 52)

As we can see, animal jokes may involve a playful use of speech acts, and this is not special or peculiar to this genre - except, of course, for the fact that in them, just like in animal folk tales, animals are able to use speech acts.

\section{Animal jokes that break conversational maxims and evoke implicatures}

Grice (1975) was not explicit about how humour touches on his Cooperative Principle and four Kantian categories, but various authors have pointed out that one essential ingredient of humour is the non-observance of his conversational maxims (e.g. Attardo 1994: 271-292, Dynel 2009, Yamaguchi 1988) as well as Leech's (1983, 2014) maxims of politeness (Goatly 2012: 224-245, Nemesi 2012, 2015). Two problems immediately emerge: what type(s) of non-observance of a maxim can be detected in a joke, and is it the joke character or the joke teller who breaks the maxims? In the following joke (15), it is the aggressive piglet again who is not making his contribution as informative as required (thus, infringing the first maxim of Quantity) without realizing it:

(15) The aggressive piglet goes to the railway station to buy a ticket. He says to the person behind the counter:

"I want a return ticket!"

"Where would you like to go?"

"What do you mean where? There and back!"12

(AK. 6)

In contrast, in (16), it is the joke teller who exploits the second maxim of Manner (“Avoid ambiguity") by a homonymous pun on the word bark (cf. Ross 1998: 17):

11 Az öreg Pista bácsi átmegy a szomszédjához látogatóba. Bekiabál a kertkapun, mire megjelenik egy hatalmas komondor, és megszólal:

- Nincs itthon a gazdám!

Az öreg úgy megijed, hogy elájul. Amikor a kutya nyelvcsapásaitól magához tér, azt mondja:

- Te, hát ugatni nem tudsz?

Mire a kutya:

- Tudok én, csak nem akartam magát megijeszteni.

12 Az agresszív kismalac megy a vasútállomásra jegyet venni. Mikor a pénztárhoz ér, azt mondja:

- Egy retúrjegyet kérek!

- Hova? - kérdi a jegyárus.

- Hogyhogy hova? Oda-vissza! 
(16) Q: What do dogs and trees have in common?

A: Their bark.

(AA. 7)

That is to say, maxims can be exploited not only for indirectly conveying a proposition but for achieving a particular perlocutionary effect as well.

The typology of implicatures introduced by Grice (1975) is rather simple (albeit not uncontroversial): a distinction is made between conventional and conversational implicatures, and the latter are subdivided into particularized and generalized ones. A generalized conversational implicature (abbreviated to GCI) is a default inference we normally draw from the use of a certain form of expression in an utterance unless there is specific contextual information that defeats it. Levinson (2000) explores this sort of implicature in detail. According to him, one of the general heuristics the processing of GCIs rests on is "What isn't said, isn't", that is, "Do not provide a statement that is informationally weaker than your knowledge of the world allows" (cf. Grice's first maxim of Quantity: "Make your contribution as informative as required"). GCI jokes are exemplified by (17), in which the expression wanted to bite implies that the dog did not, and then the joke continues and becomes clear that it actually did:

(17) "Hello, neighbour, your dog wanted to bite me yesterday!"

"How do you know it wanted to bite you?"

“How do I know? Well, if it didn’t want to, it wouldn’t have bit me, would it!”13 (HÁv. 101, LVk. 36)

What makes this joke sound so dead-pan is that GCIs are so natural that cancelling them is quite rare and strange (see Mayol and Castroviejo 2013).

Particularized conversational implicatures (PCIs), as opposed to GCIs, are generated by virtue of specific contextual assumptions. They occur in jokes much more often, and it is not necessary for them to be cancelled. In the punch line of (18), Mr Longbottom implicates that his wife talks too much:

(18) $\mathrm{Mr}$ and Mrs Longbottom are looking at the hippopotamus at the zoo. $\mathrm{Mr}$ Longbottom turns to his wife: "See what a big mouth the hippo has, and still, it keeps it shut?!"14

(HÁv. 57, LVk. 32)

13 - Szomszéd, a maga kutyája tegnap meg akart harapni...

- Honnan veszi, hogy meg akarta?

- Na, hallja! Ha nem akart volna, nem tette volna meg!

14 Petrence a nejével a vízilovat nézegeti az állatkertben.

- Látod, szívem - fordul Petrence az asszonyhoz -, mekkora szája van, és mégsem szól egy szót sem!? 
In (19), in the light of the context, it can easily be inferred from the last turn of the joke that the magpie stole both the golden watch and the cow. However, the magpie does not want to reveal this fact, it just blurts out some clues. Hence, the PCI here is generated by the joke teller:

(19) The owl, the crow and the magpie are sitting on the same branch.

The owl says, "Imagine, I got a golden watch as a gift!"

The crow says, "Oh, and I got a cow."

The magpie doesn't say anything.

The next day the three are sitting on the same branch again.

The owl says, "My watch is nowhere to be found."

The crow says, "My cow is gone, too."

The magpie doesn't say anything.

The next day they are sitting on the same branch in silence, when the magpie says, "Oh my, it's 6 o'clock. I must be off to milk the cow." 15

(AK. 46, LVk. 40)

As the above examples show, conversational maxims and implicatures are creative components of the humour in (animal) jokes - in effect, they provide the simplest explanation for the source of humour in most cases.

\section{Animal jokes that seem to defy the principle of relevance}

Sperber and Wilson's (1995 [1986]) relevance theory states that the main underlying principle of human cognition is efficiency: the goal is to gain as much information as possible with the least investment of mental effort. This is also true of linguistic communication: we seek relevance in what we hear and read. Seen from this angle, humour can originate from waiting in vain to learn something new and useful (the punch line is, paradoxically, that there is no real punch line):

15 Üldögél az ágon a bagoly, a szarka és a varjú. Azt mondja a bagoly:

- Képzeljétek, kaptam egy aranyórát.

A varjú:

- Nekem meg van egy tehenem.

A szarka egy szót sem szól.

Másnap megint együtt ülnek az ágon, s azt mondja a bagoly:

- Sajnos, eltűnt az órám.

- Nekem meg a tehenem - dünnyögi a varjú.

A szarka most is hallgat.

Harmadnap csöndben ülnek az ágon mind a hárman. Egyszer csak megszólal a szarka:

- Úristen, most látom, már hat óra. Mennem kell fejni... 
(20) In a magical kingdom, far, far away, beyond the Seven Seas, that's where the rabbit lives. One morning he gets up, opens the window, looks out and says: "Oh my, I live so frigging far!" 16

(LVk. 46)

It is a common strategy of humour to sketch a coherent and seemingly appropriate context - the first interpretation that comes to mind, a process governed by the communicative principle of relevance, which postulates that every act of overt communication conveys a presumption of its own optimal relevance - only to be subsequently invalidated and replaced with another one (Yus 2003, 2016), as conceptualized by Raskin (1985) in terms of script switching, also known as gardenpath humour (Dynel 2009, Yamaguchi 1988) and forced reinterpretation (Ritchie 2004). In joke (21), on the third occasion, the hunter wanders into a train tunnel rather than a bear's den:

(21) Bandaged from head to toe, two men are lying in adjacent beds in a hospital ward. After a while, they strike up a conversation. One of them recounts how he got into a car crash, then asks the other man what happened to him.

"A hunting accident," says the other man.

"What happened? Tell me if it's not much trouble."

"I'll be happy to. I was invited to the neighbouring country by my hunter friends, and that's when it happened. We hunted for bear, pursuers in the front, the hunters behind. Suddenly I saw a bear's den and yelled, 'Anybody in there?' A bear came out, and I shot it between the shoulders, then the pursuers skinned it. Half an hour later I saw an even bigger den, and again I yelled, 'Anybody in there?' and an even bigger bear came out, and I shot it between the eyes, thinking how lucky I was. Then an hour later I saw an enormous cave, the likes of which I'd never seen before, and I yelled, 'Anybody in there?' and out came the Prague Intercity."17 (LÁv. 40)

16 Árkon és bokron túl, az Óperenciás tengeren is túl, de még az üveghegyen is túl, lakik a nyuszika. Egy reggel felkel, kinyitja az ablakot, kihajol, és így szól:

- Hogy én milyen rohadt messze lakom!

17 Két tetőtől talpig bekötözött ember fekszik egy kórház kétágyas szobájában. Ahogy állapotuk javul, beszélgetni kezdenek. Egyikük elmondja, hogy ôt autóbaleset érte, és kérdezi a másikat, vele ugyan mi történt.

- Vadászbaleset - feleli a másik beteg.

- Vadászbaleset? - mondja a kérdező. - Mesélje el, ha nem fárasztja.

- Nagyon szívesen. A szomszéd országba hívtak meg vadászbarátaim, ott történt az eset. Medvére mentünk, elöl a hajtók, mögöttük a vadászok. Egyszer csak látok egy kis barlangot, bekiáltok: brumm, brumm! Kijött egy kis medve, szabályosan lapockán lőttem, a medve kimúlt, a hajtók megnyúzták. Félóra múlva egy nagyobb barlang ötlik a szemembe, oda is bekiáltok: brumm, brumm! Kijött egy nagyobb medve, pont szemen találtam, azonnal lefeküdt. Örültem, milyen szerencsém volt. Vagy egy óra múlva óriási barlangot látok, ekkorát talán még nem is láttam. Oda is bekiáltottam: brumm, brumm, erre kijött a prágai gyors. 
Relevance theory suggests that Grice's (1975) insights into conversation and utterance interpretation are worth exploring further. The notion of explicature, recovered by a combination of decoding and inference in determining the explicit content of an utterance, was coined by Sperber and Wilson (1995 [1986]) on the analogy of Grice's implicature. By explicature, the often incomplete and ambiguous linguistic form of an utterance can be made more precise. For example, the deictic reference of it in the second turn of the joke (22) is context-dependent. Based on the mailman's first utterance, the hearer is inclined to think of the wound on the leg caused by the dog as the most relevant interpretation. The mailman thinks otherwise, meaning the leg before the dog bite. Let us call this type of joke an explicature joke:

(22) Mailman: "Your dog bit my leg!"

Woman: "Did you put anything on it?"

Mailman: "No, he seemed to like it just the way it was."

(AA. 29)

The communicative principle of relevance automatically guides the comprehension procedure, and one cannot "obey it", "violate it", or "switch it off" when processing information. Jokes and other humorous texts, however, raise the tricky question of how this inviolable principle can account for an intended interpretation which at first is not relevant enough to confirm the presumption of relevance (Attardo 2017: 182). Two further theory-internal issues that need to be addressed are: (a) Is humorous effect a kind of cognitive benefit and contextual effect? (b) Does amusing the hearer fall within the scope of ostensive-inferential communication and the informative intention? (Nemesi 2019, Piskorska 2005; cf. the notion of "layering" in Clark [2013: 144; cf. Clark 1996: 353-384], the idea of "positive/negative non-propositional effect" in Yus [2016: 31, 54-59], and Zuo's [2020] proposal to treat the recognition of the communicator's "affective intention" as an integral part of the relevance-driven interpretation process).

\section{The role of viewpoint in animal jokes}

On a functional cognitive approach, it is a crucial aspect of the meaningful functioning of language that every utterance is produced from a particular point of view but can be interpreted from different points of view (Tátrai 2011, 2015; Verschueren 1999). Interactants in a given situation follow and direct each other's attention to the matters of the world in order to share or modify each other's mental representations and orientations. People naturally tend to regard their own egocentric viewpoint as the most natural starting point, but as social-cognitive beings they are expected to be able to adopt their partners' perspectives (Tomasello 1999). Some scholars hold 
that conversational participants are generally not egocentric (e.g. Bezuidenhout 2013). On the other hand, characters in stupidity jokes (cf. Davies 2011) often fail to shift their egocentric perspective. Here is an example:

(23) "Doctor, what do you think, is trout really so healthy?"

"I think so... At least, I have never had to treat one before." ${ }_{18}$

(LVk. 35)

In (23), the doctor character is either serious, ignoring the partner's perspective on healthy eating or, less likely, deliberately joking. In (24), one of the lab mice takes a funny perspective (in effect, the reverse of the scientist's viewpoint) and cannot realize its relativity or even inadequacy:

(24) Two lab mice are talking.

"I can see you're living well, you have gained weight."

"Yes. I managed to train my scientist. Every time I run up this ladder, he gives me a piece of cheese." 19

(LVk. 44)

There are further humorous tactics involved in "point of view operation" or "perspective manipulation" (Verschueren 1999: 97). One is to include a character who steps out of his or her own perspective and takes on another one, so absurd (albeit not totally unrelated) that it makes the joke audience smile or laugh, as is the case with the young male seal in (25), who adopts the human viewpoint of fighting for the preservation of biodiversity:

(25) The young male seal is courting a young female seal, but she is playing hard to get. "I can't believe this!" the young male fumes, "We're on the list of endangered species and she's playing hard to get!" 20

(AK. 78, LVk. 46)

Speakers mutually help each other in taking the proper perspective with various linguistic and non-linguistic tools; for instance, with address forms (cf. Németh T.

18 - Mondja, doktor úr, tényleg olyan egészséges a pisztráng?

- Minden bizonnyal... Legalábbis nálam még egyetlen pisztráng sem gyógykezeltette magát.

19 Két laboratóriumi egérke beszélget:

- Látom, jól megy a sorod, egészen kigömbölyödtél.

- Igen. Sikerült beidomítanom a tudósomat: valahányszor felszaladok ezen a létrán, mindig ad egy darab sajtot.

20 A fókafiú udvarol a fókalánynak, de az erősen kéreti magát.

- Ez nem igaz! - dühöng a fókafiú. - Rajta vagyunk a kihaló állatok listáján, ez meg itt kéreti magát! 
2015) and other linguistic clues of (im)politeness, intonation, eye movement, and gestures. If the speaker uses these viewpoint indicators incorrectly, in a misleading or teasing way, the incongruence that follows may produce humour. Consider (26):

(26) Georgie: "Yesterday I came face to face with a lion!"

Porgie: "Weren’t you scared?"

Georgie: "Naw. I just turned away and walked past his cage."

(AA. 23)

The joke (27) can be thought of as the inverse of (26): it is the hearer (Jamie) who misinterprets the verbal and non-verbal clues provided by the speaker (Amy) about her point of view:

(27) Amy: "Hey, your dog just bit my ankle."

Jamie: "What did you expect? She's just a small dog, she can't reach any higher!" (AA. 7)

Because speakers' intentions and perspectives are closely interconnected, hearers attempt to evaluate them together and to align them (Németh T. 2015). Humour is partly predictable from the perceived discrepancy between the interlocutors' viewpoints as a form of incongruity. Ritchie (2006: 265) adds that "certain jokes seem to operate by merely mentioning some incongruous perspective in a very oblique way, adopted neither by the audience nor by any story-character", but being accessible to the audience. Consequently, several patterns of "nested viewpoints" can be observed in humorous texts.

\section{The intersecting circles model}

In recent years, new and useful insights into the semantic and pragmatic typology of verbal humour have been offered by Dynel (2009, 2012) and Yus $(2013,2016)$. Dynel's threefold classification into garden-path, crossroads, and red-light mechanisms concentrates on how the punch line relates to the set-up (the preceding portion of the text), emphasizing that not all punch lines force a reinterpretation of the set-up (cf. Ritchie 2004). Yus, who works within a relevance-theoretic framework, presented a more complex taxonomy, the intersecting circles model, which distinguishes between 7 types of jokes, indicated by numbers in Figure 1. 


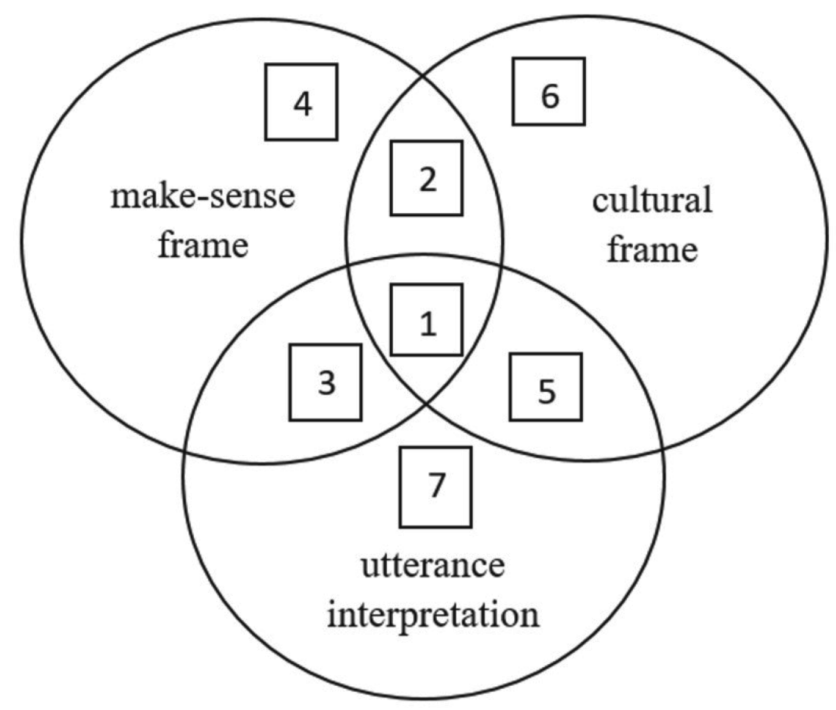

Figure 1. The intersecting circles model of humorous communication

The three "pure" types are 4, 6, and 7. The "make-sense frame", as proposed by Yus, is a blanket label for schemas associated with words, scripts associated with event sequences, and frames associated with situations; that is, it corresponds closely to what Raskin (1985) calls "script". In jokes of type 4, the interpretation hinges on the make-sense frame. This is illustrated in (28), a very simple gardenpath joke, where the rabbit corrects the fox's mistaken make-sense frame:

(28) The young rabbit is sitting by the stream, intent on watching his reflections and squeezing red dots on his face. The fox walks by and grins.

"Puberty?" he asks.

"Nope," the rabbit says, "pellets."

(AK. 19, LÁv. 76, LVk. 49)

A cultural frame is stereotypical knowledge about the way of thinking characteristic of the members of a community (cf. Kianbakht 2020). In Hungary, these include the stereotypes that men like pálinka (Hungarian fruit brandy), and women like looking at themselves in the mirror. Projected onto an animal joke, we get, for instance, the following:

21 A nyuszika a patak tükrében piros pöttyöket nyomogat az arcán. Arra sétál a róka. Jót mosolyog a látványon:

- Mi van, nyuszika? Pubertás?

- Túrót. Sörét. 
(29) "Hey, dad, did you see? There is a male fly and a female fly here." "What makes you so sure?"

"Well, this one landed on a bottle of pálinka, while that one has been crawling around on the mirror for hours." 22

(HÁv. 75, LVk. 34)

The joke (29) represents type 6 in the intersecting circles model and perhaps the crossroads mechanism in Dynel's terms, given that "the hearer cannot successfully complete the comprehension process of the set-up [that includes inexplicable premises, the focal incongruity] until the punch line (frequently also incongruous) is introduced, after which any incongruity is resolved" (2012: 6).

Type 7 is exemplified by (30), in which the utterance interpretation of "Strange... it looks so smart!" results in a humorous implicature, while the initial make-sense frame does not change, and neither does it strengthen or question any societal stereotype. As an application of the red-light mechanism, understanding it requires the hearer to follow "the interpretation path unobstructed until he/she needs to stop upon encountering the surprising red light (the punch line) diverting the interpretative process to a destination which cannot have been envisaged earlier" (Dynel 2009: 25, 2012: 16):

(30) "Isn't this dog a bit dumb?"

"This dog? He knows almost as much as I do!"

"Strange... it looks so smart!" 23

(HÁv. 100, LÁv. 52, LVk. 36)

Types 1, 2, 3, and 5 are possible combinations of the three basic types.

When trying to fit the jokes discussed so far in Yus's model, we may get the impression that some of them can be categorized unequivocally, while others are more or less problematic due to the uncertain boundaries of make-sense frames and utterance interpretation. If schemas, frames, and scripts all come under the umbrella of make-sense frame, and utterance interpretation extends to every level of meaning (explicit and implicit, coded and inferred) in a punch line, it is then difficult to think of a joke the humour of which does not depend on these. Moreover, as far as cultural frames are concerned, it is not clear why they should form a separate set: we might say that cultural frames are ultimately make-sense frames (see the animal

22 - Papa, látod? Van itt egy hímnemú, meg egy nőnemú légy.

- Honnan tudod ilyen biztosan?

- Mert az egyik a pálinkásüvegre szállt, a másik meg a tükrön mászkál órák óta.

23 - Aztán nem buta ez a kutya?

- Ez? Ez, kérem, majdnem annyit tud, mint én...

- Pedig milyen okosnak látszik! 
stereotypes). Now let us group all the thirty animal jokes cited above according to the seven types of the intersecting circles model:

Type 1:

Type 2: (25)

Type 3: (1), (6), (13), (21)

Type 4: (7), (8), (10), (14), (23), (24), (26), (27), (28)

Type 5: (3), (4), (18), (19)

Type 6: (11), (29)

Type 7: (2), (5), (9), (12), (15), (16), (17), (20), (22), (30)

\section{Conclusions}

I began this paper with the observation that though even the simplest and shortest canned jokes do not constitute a completely unified text type, their prototypical features can be easily identified. Information efficiency, i.e. the terse and tight character of jokes, is made possible by frames and scripts being activated by some keywords. Frame/script semantics has been applied to jokes since the 1980s, placing emphasis on the sudden clash of two frames/scripts at the punch line but without disclosing the pragmatic machinery that underlies comprehension in its variability and complexity. Jokes not based on script opposition may employ several other means (exaggeration, irony, impoliteness, inadequacy, inconsistency, irrelevance, irrationality, viewpoint manipulation, etc.) within the same script or frame. The linguistic underdeterminacy of the proposition expressed by an utterance (Carston 2002) and the recovery of the full meaning condensed into a joke leave plenty of room for pragmatic enrichments and inferences, and this is why the creation and processing of humorous texts cannot be modelled without an analysis of pragmatic processes.

All the major theories of pragmatics are able to capture and explain certain elements of humour. However, none of them was designed to tackle such a challenge. Actually, humorous phenomena provide a test for speech act theory, Gricean and neo-Gricean pragmatics, relevance theory and functional cognitive pragmatics that sheds light on their strengths and weaknesses. At the same time, these general theories of language use can hugely contribute to the study of humour. They turned out to be partial in themselves, but integrating them with frame/script theory may bring a new era to linguistic research into humour. Instead of trying to (im)prove (on) one or another as being the correct one, it is time to harmonize them, creating a framework as flexible as the subject matter under investigation.

The semantic and pragmatic mechanisms we have highlighted in animal jokes are not different in kind from those revealed in other jokes and in other forms, text types, and genres of verbal humour. In this sense, they are not unique. Their 
popularity lies in their psychological and cultural-anthropological nature. Animals attract both children and adults, and their importance in human thinking is well attested to in research on folklore and the history of art. The proximity of livestock and domesticated animals, the variety of wild animals, people's fear of dangerous animals or their dominance of defenceless ones, the beauty, striking outer features, and other real or imagined characteristics of some species all have a profound effect on our imagination. Animal stories and jokes anthropomorphize them, projecting onto them various human features, instincts, and stereotypes in order to entertain, relieve stress, formulate morals, and so on (cf. Martin 2007). It is the task of intercultural humour studies to examine whether animal jokes constitute a cultural universal, to explore the similarities and differences among the animal jokes of various languages and cultures, and to discover what imprint is left by the fauna surrounding a community in that community's jokes (for a discussion of Australian animal jokes, see Andor 2018).

\section{References}

Abelson, Robert P. 1981. Psychological status of the script concept. American Psychologist 36(7): 715-729.

Alexander, Richard J. 1997. Aspects of Verbal Humour in English. Tübingen: Gunter Narr Verlag.

Andor, József. 1985. On the psychological relevance of frames. Quaderni di Semantica 6(2): 212-221.

- 2002. On the cohesion and coherence of animal jokes: A frame-semantic analysis of narrative structure. In Szilvia Csábi-Judit Zerkowitz (eds), Textual Secrets: The Message of the Medium, 90-101. Budapest: ELTE.

- 2014. Animal-related humor. In Salvatore Attardo (ed.), Encyclopedia of Humor Studies 1: 41-42. Thousand Oaks (CA): SAGE Publications.

- 2018. Humor-sztereotípiák ausztrál állatviccekben [Humour stereotypes in Australian animal jokes]. In Attila L. Nemesi-Anna T. Litovkina-Zsuzsanna Barta-Péter Barta (eds), Humorstílusok és -stratégiák [Humour styles and strategies], 341-351. Budapest: Tinta Könyvkiadó.

Attardo, Salvatore. 1994. Linguistic Theories of Humor. Berlin: Mouton de Gruyter.

- 2001. Humorous Texts: A Semantic and Pragmatic Analysis. Berlin: Mouton de Gruyter.

- 2017. Humor and pragmatics. In Salvatore Attardo (ed.), The Routledge Handbook of Language and Humor, 174-188. London-New York: Routledge.

Attardo, Salvatore-Jean-Charles Chabanne. 1992. Jokes as a text type. HUMOR: International Journal of Humor Research 5(1/2): 165-176. 
Attardo, Salvatore-Victor Raskin. 1991. Script theory revis(it)ed: Joke similarity and joke representation model. HUMOR: International Journal of Humor Research 4(3/4): 293-347.

Austin, John L. 1962. How to Do Things with Words. Oxford: Oxford University Press.

Bezuidenhout, Anne. 2013. Perspective taking in conversation: A defense of speaker non-egocentricity. Journal of Pragmatics 48(1): 4-16.

Brock, Alexander. 2004. Analyzing scripts in humorous communication. HUMOR: International Journal of Humor Research 17(4): 353-360.

Carston, Robyn. 2002. Thoughts and Utterances: The Pragmatics of Explicit Communication. Oxford: Blackwell.

Clark, Billy. 2013. Relevance Theory. Cambridge: Cambridge University Press.

Clark, Herbert H. 1996. Using Language. Cambridge: Cambridge University Press.

Coulson, Seana. 2001. Semantic Leaps: Frame-Shifting and Conceptual Blending in Meaning Construction. Cambridge: Cambridge University Press.

Davies, Christie. 2011. Jokes and Targets. Bloomington (IN): Indiana University Press.

Dynel, Marta. 2009. Humorous Garden-Paths: A Pragmatic-Cognitive Study. Newcastle upon Tyne: Cambridge Scholars Publishing.

- 2012. Garden paths, red lights and crossroads: On finding our way to understanding the cognitive mechanisms underlying jokes. Israeli Journal of Humor Research 1(1): 6-28.

Forgács, Tamás. 2005. „Állati” szólások és közmondások [Animal sayings and proverbs]. Budapest: Akadémiai Kiadó.

Goatly, Andrew. 2012. Meaning and Humour. Cambridge: Cambridge University Press.

Grice, H. Paul. 1975. Logic and conversation. In Peter Cole-Jerry L. Morgan (eds), Syntax and Semantics, Vol. 3: Speech Acts, 41-58. New York: Academic Press.

Haase, Donald, ed. 2008. The Greenwood Encyclopedia of Folktales and Fairy Tales, Vol. 1-3. Westport (CT): Greenwood Press.

Hancher, Michael. 1980. How to play games with words: Speech-act jokes. Journal of Literary Semantics 9(1): 20-29.

Hetzron, Robert. 1991. On the structure of punch lines. HUMOR: International Journal of Humor Research 4(1): 61-108.

Kianbakht, Sajjad. 2020. Towards a comprehensive theory of culturally constructed humour. European Journal of Humour Research 8(2): 1-24.

Leech, Geoffrey N. 1983. Principles of Pragmatics. London: Longman.

- 2014. The Pragmatics of Politeness. Oxford: Oxford University Press.

Levinson, Stephen C. 2000. Presumptive Meanings: The Theory of Generalized Conversational Implicature. Cambridge (MA): MIT Press. 
Martin, Rod A. 2007. The Psychology of Humor: An Integrative Approach. Amsterdam: Elsevier.

Mayol, Laia-Elena Castroviejo. 2013. How to cancel an implicature. Journal of Pragmatics 50(1): 84-104.

Mieder, Wolfgang. 1993. Howl Like a Wolf: Animal Proverbs. Shelburne (VT): The New England Press.

Morreall, John. 2004. Verbal humor without switching scripts and without nonbona fide communication. HUMOR: International Journal of Humor Research 17(4): 393-400.

Nemesi, Attila L. 2012. Two masters of playing with conversational maxims. In Anna T. Litovkina-Judith Sollosy-Péter Medgyes-Dorota Brzozowska (eds), Hungarian Humour, 13-30. Kraków: Tertium.

- 2015. Levels and types of breaking the maxims: A neo-Gricean account of humor. Intercultural Pragmatics 12(2): 249-276.

- 2016. Beszédaktusviccek [Speech-act jokes]. In Judit Boda-Ujlaky-Zsuzsanna Barta-Anna T. Litovkina-Péter Barta (eds), A humor nagyítón keresztül [Humour through a Magnifying Glass], 148-162. Budapest: Tinta Könyvkiadó.

-2019. Releváns-e a humor a relevanciaelméletben? [Is humor relevant to relevance theory?] Jelentés és Nyelvhasználat 6(1): 1-31. http://www.jeny.szte.hu/jeny2019-nemesial (Last accessed: 24 April 2020)

Németh T., Enikő. 2015. The role of perspectives in various forms of language use. Semiotica 203: 53-78.

Norrick, Neal R. 1986. A frame-theoretical analysis of verbal humor: Bisociation as schema conflict. Semiotica 60(3/4): 225-245.

- 1993. Conversational Joking: Humor in Everyday Talk. Bloomington (IN): Indiana University Press.

Oring, Elliott. 2019. Oppositions, overlaps, and ontologies: The general theory of verbal humor revisited. HUMOR: International Journal of Humor Research 32(2): 151-170.

Piskorska, Agnieszka. 2005. Can we have a recipe for humour in relevance theory? In Piotr Cap (ed.), Pragmatics Today, 245-253. Frankfurt am Main: Peter Lang Verlag.

Raskin, Victor. 1985. Semantic Mechanisms of Humor. Dordrecht: D. Reidel.

- 2017. Script-based semantic and ontological semantic theories of humor. In Salvatore Attardo (ed.), The Routledge Handbook of Language and Humor, 109125. London-New York: Routledge.

Raskin, Victor-Christian F. Hempelmann-Julia M. Taylor. 2009. How to understand and assess a theory: The evolution of the SSTH into the GTVH and now into the OSTH. Journal of Literary Theory 3(2): 285-311.

Ritchie, Graeme. 2004. The Linguistic Analysis of Jokes. London and New York: Routledge. 
- 2006. Reinterpretation and viewpoints. HUMOR: International Journal of Humor Research 19(3): 251-270.

Ross, Alison. 1998. The Language of Humour. London-New York: Routledge.

Schank, Roger C.-Robert P. Abelson. 1977. Scripts, Plans, Goals, and Understanding: An Inquiry into Human Knowledge Structures. Hillsdale (NJ): Lawrence Erlbaum. Searle, John R. 1965. What is a speech act? In Max Black (ed.), Philosophy in America, 221-239. London: George Allen \& Unwin Ltd.

- 1969. Speech Acts: An Essay in the Philosophy of Language. Cambridge: Cambridge University Press.

Sperber, Dan-Deirdre Wilson. 1995 [1986]: Relevance: Communication and Cognition. Oxford: Blackwell.

Szirmai, Éva-Szergej Tóth-Edit Újvári (eds). 2018. Állati jelek, képek és terek I-II [Animal signs, images and spaces, Vol. 1-2]. Szeged: Szegedi Egyetemi KiadóJuhász Gyula Felsőoktatási Kiadó.

T. Litovkina, Anna. 2016a. "Do You Serve Lawyers and Politicians Here?" Stereotyped Lawyers and Politicians in American Jokes and Anti-Proverbs. Komárno (Komárom): Univerzita J. Selyeho (Selye János Egyetem).

- 2016b. The lawyer as animal in American lawyer jokes. European Journal of Humour Research 4(1): 3-13.

Tátrai, Szilárd. 2011. Bevezetés a pragmatikába. Funkcionális kognitív megközelítés [An Introduction to Pragmatics: A Functional Cognitive Approach]. Budapest: Tinta Kiadó.

- 2015. Context-dependent vantage points in literary narratives: A functional cognitive approach. Semiotica 203: 9-37.

Tomasello, Michael. 1999. The Cultural Origins of Human Cognition. Cambridge (MA): Harvard University Press.

Verschueren, Jef. 1999. Understanding Pragmatics. London: Arnold.

Werness, Hope B. 2003. The Continuum Encyclopedia of Animal Symbolism in Art. New York: Continuum.

Yamaguchi, Haruhiko. 1988. How to pull strings with words: Deceptive violations in the garden-path joke. Journal of Pragmatics 12(3): 323-337.

Yus, Francisco. 2003. Humor and the search for relevance. Journal of Pragmatics 35(9): 1295-1331.

- 2013. Analyzing jokes with the Intersecting Circles Model of humorous communication. Lodz Papers in Pragmatics 9(1): 3-24.

- 2016. Humour and Relevance. Amsterdam: John Benjamins.

Zuo, Baiyao. 2020. Why does humor fail or occur unexpectedly? - An account of humor within an extended relevance theory. Journal of Pragmatics 160: 1-13. 


\section{Sources of the jokes}

AA. = Schultz, Sam. 2004. Animal Antics: The Breast Jokes Ever! Minneapolis (MN): Carolrhoda Books.

AK. $=$ Az agresszív kismalac és más állatviccek [The Aggressive Piglet and Other Animal Jokes]. Collection by KÁGÉ. Budapest: K.u.K. Kiadó. 2004.

HÁv. = 300 állatvicc [300 Animal Jokes]. Compiled by József Köves and László Menkó. Budapest: Minerva Kiadó. 1987.

LÁv. = A legjobb állatviccek [The Best Animal Jokes]. Compiled by Ákos Moré. [Budapest]: Könyvkuckó Kiadó. 1996.

LVk. = A legnagyobb vicckönyv 10000 viccel [The Biggest Joke Book with 10 Thousand Jokes]. Compiled by József Köves. Budapest: K.u.K. Kiadó. 1999. 